\title{
Uwagi o przygotowaniu zawodowym duchownych senatorów Rzeczypospolitej w latach 1501-1587
}

okresie staropolskim każdy biskup-ordynariusz był jednocześnie senatorem Rzeczypospolitej. Według konstytucji sejmu lubelskiego z $1569 \mathrm{r}$. senatorami duchownymi było: 2 arcybiskupów (gnieźnieński i lwowski) oraz 13 biskupów (krakowski, kujawski, wileński, poznański, płocki, warmiński, łucki, przemyski, żmudzki, chełmiński, chełmski, kijowski i kamieniecki) ${ }^{1}$. Z inicjatywy Stefana Batorego w 1583 r. papież Grzegorz XIII powołał do życia diecezję inflancką, której zarządca też wszedł do senatu. W XVI w. duchowny senator Rzeczypospolitej nie był pojęciem tożsamym z członkiem Episkopatu. Przedmiotem mojej analizy będzie zbiorowość biskupów-senatorów, którzy zarządzali diecezjami w latach 1501-1587, czyli od początku panowania Aleksandra Jagiellonczyka do elekcji Zygmunta III Wazy. Wspomniane 86 lat było okresem stosunkowo jednolitym pod względem gospodarczym, sprawnie funkcjonowały wszystkie instytucje państwowe, dobrze układała się współpraca między izbą poselską a senatem.

W badanym okresie administrowaniem 16 stolic biskupich zajmowało się 99 biskupów ordynariuszy. W Rzeczypospolitej biskupów mianował król (od czasów Kazimierza Jagiellończyka). Na wieść o śmierci biskupa władca wysyłal do wlaściwej kapituły swego posła z zaleceniem osadzenia królewskiego kandydata na wakujące miejsce. Zdarzało się, że papież miał swojego kandydata. Po zmarłym w Rzynie w 1522 r. Erazmie Ciołku, biskupie płockim, papież Adrian IV chciał osadzić w Plocku Jana Albrechta Hohenzollerna. W tym jednak przypadku kandydat ów był niewygodny dla Polski, a papież naruszał uprawnienia nominacji biskupich. W tej sytuacji Albrecht nie mógl objąć stolicy biskupiej. Andrzej Krzycki został zatwierdzony przez papieża na biskupa płockiego 29 kwietnia 1527 r., kapituła zaś wybrała go biskupem dwa tygodnie później - elekcja ta była więc tylko formalnością ${ }^{2}$.

Jedynie biskupstwo warmińskie zastrzegło sobie prawo, w myśl którego ordynariuszem tej diecezji mogła zostać tylko osoba wchodzạca w skład jej kapituły - dla- 
tego władca wcześniej wprowadzał w jej szeregi swojego kandydata. Tak było z Janem Dantyszkiem i Marcinem Kromerem.

Fakt, że biskup byl senatorem, bardzo podnosil jego znaczenie. Biskupstwo byto zatem atrakcyjne jako godność kościelna i państwowa, a uposażenie w dobra ziemskie jeszcze tę atrakcyjność zwiększało. Biskupstwa byly nadawane wedlug pewnej hierarchii, od najskromniejszych (o niskich dochodach i dalekim miejscu w senacie) po najbogatsze i najbardziej wpływowe.

Kandydat na biskupa, oprócz poparcia królewskiego, musial, według obowiązującego prawa, spełniać wymagania formalne, które mógł uzupełnić, jeśli ich nie posiadał (np. święcenia), lub uzyskać dyspensę papieską. Zdarzało się, że król zwracal się do papieża $\mathrm{z}$ prośbą o dyspensę $\mathrm{z}$ racji zbyt młodego wieku kandydata, nieposiadania święcen kapłańskich lub stopni naukowych, pochodzenia z rodziny dysydenckiej albo gdy sam kandydat był wcześniej innowierca (np. Jan Dymitr Solikowski, Jan Drohojowski). Ponadto dobry pasterz musial być pobożny i mieć odpowiednią postawę moralną. Hasło Soboru Trydenckiego: Biskup dla diecezji nie miało w Rzeczypospolitej szans pełnej realizacji, gdyż biskup był także funkcjonariuszem państwowym i musiał dzielić obowiązki między diecezję a senat. Dlatego przy nominacji pytano nie tylko, jakiego pasterza będzie miała diecezja, ale jakiego senatora otrzyma Rzeczpospolita ${ }^{3}$.

Najczęściej droga do biskupstwa wiodła przez dwór królewski. Z badań A. Wyczańskiego, M. Korolki i L. Kieniewicza wynika, że większość sekretarzy Zygmunta Starego, Zygmunta Augusta i Stefana Batorego kończyla karierę przy królu, otrzymując w nagrodę godność biskupa-ordynariusza ${ }^{4}$. Z ogólnej liczby 99 biskupów 57 wcześniej pełniło funkcję sekretarza królewskiego, czyli co drugi purpurat w XVI w. wywodził się z szeroko rozumianego sekretariatu władcy. W tym przypadku nominacja była nagroda za pracę wykonana na rzecz monarchy. Najczęściej takie wyróżnienie spotykało królewskich dyplomatów (Jan Dantyszek był przedstawicielem Zygmunta I na dworze hiszpanskim, zanim został biskupem chełmińskim) i posłów (Wawrzyniec Międzyleski przed nominacją na biskupstwo kamienieckie posłował z polecenia Zygmunta I na Litwę, Mazowsze i do Rzymu). Również sprawowanie ważnych funkcji na dworze któregoś aktualnego ordynariusza ułatwiało drogę do stolicy biskupiej. Szkoły i dwory biskupie były wylęgarnią przyszłych nominatów (np. dwory: Hozjusza, Krzyckiego, Maciejowskiego, Myszkowskiego, Tomickiego). Młodzi ludzie wysyłani na studia do Krakowa i poza granice Rzeczypospolitej, przeważnie na koszt rodziców, krewnych czy bogatych protektorów, właśnie w tym momencie rozpoczynali przyszłą karierę. Marcin Kromer pisal: Wszyscy tak samo niezamożni, jak $i$ bogaci, tak szlachta, jak $i$ lud prosty, staraja się posyłać mtodych chtopców do szkót i na naukę $e^{5}$. 
Wtedy, w XVI stuleciu, szlachta zaczęła doceniać rangę nauki, a właściwie edukacji swoich dzieci. Wysylanie na studia, zapoznawanie się z kulturą obcych krajów, uczenie się języków obcych (zwłaszcza niemieckiego i włoskiego) miały ułatwić start młodzieży szlacheckiej. Powszechna stała się maksyma kasztelana bracławskiego Wasyla Zahorowskiego, który w swoim testamencie napisał synowi: wolę ci zostawić dobre wychowanie niz majatek ${ }^{6}$. Otóż dobre wychowanie oznaczało po prostu wyksztatcenie. Ku takiemu przekonaniu sklaniali się zapewne wszyscy ojcowie, którzy wysyłali swoich synów na obce uniwersytety. Młodzi ludzie po powrocie do kraju zaczynali służbę w kancelarii króla, królowej, administracji biskupiej, gdzie nabierali praktycznych umiejętności kancelaryjnych. Szesnastowieczny pęd do wiedzy znajduje swoje przełożenie w obrazie zainteresowań intelektualnych ówczesnych duchownych senatorów Rzeczypospolitej (mecenat naukowy, artystyczny, bibliofilstwo).

Na 99 ordynariuszy diecezjalnych zarządzających 17 diecezjami w latach 1501-1587 aż 76 (77\%) otarło się o jakąś uczelnię. Większość zaczynala edukację w Akademii Krakowskiej. Nazwiska 45 (60\%) przyszłych biskupów można odnależć w jej aktach, 3 ukończyło Akademię Lubrańskiego w Poznaniu, 2 szkołę w Chełmnie, po jednym - kolegium jezuickie w Wilnie i Pułtusku oraz szkołę katedralna we Wloclawku.

Około połowy biskupów kończyło naukę w szkołach działających na terenie Rzeczypospolitej, a prawie $50 \%$ kształciło się jeszcze dalej za granicą. W metrykach uniwersytetów w Bolonii i Padwie figuruje 17 nazwisk przyszłych polskich senatorów duchownych, 2 zapisało się na uniwersytety w Sienie (Maurycy Ferber, Jan Chojeński) i Perugii, jeden zatrzymał się w Ferrarze. Od lat 50. XVI w. widać duże zainteresowanie młodzieży polskiej rzymską Sapienza, gdzie wśród jej słuchaczy można odnaleźć 19 przyszłych polskich biskupów. Tylu jest Polaków, którzy udaja się do Wtoch i Rzymu, jedni dla nauki, drudzy dla zwiedzania, że nie mogę nastarczyć im dawania listów polecajacych - pisał w 1578 r. nuncjusz apostolski Caligari ${ }^{7}$. Niemieckie uniwersytety wśród polskich katolików cieszyły się mniejszą popularnością. W Wittenberdze studiowali m.in. Stanisław Karnkowski i Adam Konarski, w Lipsku biskup chełminski Tiedeman Giese, we Frankfurcie nad Odrą Łukasz Kościelecki i Adam Konarski, jeden przyszły biskup trafił na uniwersytet w Kolonii (Fabian Luzjański). Zupełnie sporadycznie Polacy zatrzymywali się na uniwersytetach w Leodium (Walenty Herburt), Paryżu (Andrzej Zebrzydowski), Orleanie i Madrycie (Piotr Wolski).

W grupie studiujących biskupów $67 \%$ słuchało wykładów na co najmniej dwóch uczelniach, około zaś 33\% przewinęło się przez trzy lub więcej. Zdecydowana przewaga uczelni włoskich wskazuje na dominujace w wykształceniu polskich biskupów prawo, a nie teologię. Przygotowanie prawnicze było potrzebne w przyszłej pracy kancelaryjnej (królewskiej, kościelnej). 
Tylko niektórzy polscy biskupi-szlachcice kończyli studia ze stopniami naukowymi. W latach 1501-1589 dyplomami legitymowało się 18 biskupów (23\%). Byly to przeważnie doktoraty obojga praw, dekretów, jeden doktorat medycyny oraz magisterium sztuk wyzwolonych. Z naszych danych wynika, że byli to następujący biskupi: Jan Chojeński, Mikołaj Chrapicki, Andrzej Czarnkowski, Jan Dziadulski, Stanisław Hozjusz, Benedykt Izbieński, Jan Konarski, Franciszek Krasiński, Marcin Kromer, Jan Lubrański, Samuel Maciejowski, Wawrzyniec Międzyleski, Jerzy Pietkiewicz (dyplom doktora medycyny), Leonard Słończewski, Wojciech Starożrebski.

Brak stopnia nie był przeszkoda, przynajmniej w pierwszej połowie XVI w., do ubiegania się o stolicę biskupią, chociaż Sobór Trydencki stawiał takie wymagania. Kandydat na biskupa powinien mieć doktorat, magisterium lub licencjat teologii bądź prawa kanonicznego, lub też oficjalne świadectwo jakiejś akademii, że jest zdolny do nauczania innych ${ }^{8}$. Dokumenty potwierdzające stopień naukowy, które kandydaci musieli przedłożyć wraz z innymi dokumentami w Rzymie, odgrywały dużą rolę $w$ trakcie procesów informacyjnych przeprowadzanych przed nominacjami lub przeniesieniami biskupów ${ }^{9}$. Ale przepisy te właściwie zaczęły obowiązywać od lat dwudziestych XVII w. Nie wiadomo więc, ilu biskupów w XVI w. otrzymało dyspensę z powodu braku stopni naukowych. Dysponujemy danymi dopiero z lat 1586-1615, z których wynika, że 60\% biskupów dawnej Rzeczypospolitej nie miało stopni naukowych ${ }^{10}$.

Od 1430 r. obowiązywało w Rzeczypospolitej prawo, że biskupem diecezjalnym mógl być tylko szlachcic. Dla ludzi niższego stanu awans był możliwy przez wykształcenie i nobilitację. W XVI w. wśród biskupów-senatorów szlachcicami nobilitowanymi byli m.in. Marcin Kromer i Stanisław Hozjusz. Tak więc urodzenie zastępowało tytuły naukowe. W XVI w. nie było w zwyczaju, aby dyplom wienczył lata nauki. Zasada taka obowiązywała cały stan szlachecki - nie tylko tych, którzy w przyszłości wybierali karierę kościelną. Przebywający w Polsce w latach 1630-1636 nuncjusz apostolski O. Visconti pisał, że szlachta polska nie stara się o stopnie doktorskie, uważając je za stosowne dla mieszczan i chłopów ${ }^{11}$.

Duchowni senatorowie, których nazwisk nie znajdujemy w zachowanych spisach szkolnych (w metrykach uniwersyteckich, wykazach kolegiów jezuickich itp.), obejmują grupę 23 osób (ok. 23 \% badanych). Są wśród nich czterej arcybiskupi lwowscy - Jan Sienieński, Piotr Starzechowski, Paweł Tarło, Bernard Wilczek, jeden prymas - Jan Łaski, biskup poznański, wcześniej kanclerz wielki koronny - Paweł Dunin Wolski, biskup kujawsko-pomorski - Łukasz Górka, biskup płocki - Wincenty Przerębski (Przerembski). Nie wiemy nic lub bardzo mało o edukacji ordynariuszy diecezji wschodnich. Czterech biskupów żmudzkich (Melchior Giedroyć, Mikołaj Wieżgajłło, Wacław i Wiktoryn Wierzbiccy) nie odnotowały żadne 
metryki uniwersyteckie. O edukacji szkolnej dwóch biskupów chełmskich (Adam Pilichowski, Mikołaj Wolski) nie zachowały się informacje źródłowe bezpośrednie $\mathrm{z}$ archiwów uniwersyteckich. Tak samo w przypadku trzech biskupów łuckich (Jerzy Chwalczewski, Walerian Protasewicz, Wojciech Radziwiłł), trzech kijowskich (Mikołaj Pac, Bartłomiej Soloznicki, Franciszek ze Lwowa), po jednym przemyskim (Wojciech Baranowski), inflanckim (Aleksander Mieliński) oraz kamienieckim (Piotr Arcichowski).

Brak danych o edukacji tych biskupów może wynikać z niedostatków dokumentacji źródłowej. Niektórzy studiowali, ale nie dopełniali formalności i nie wpisywali się do metryk uniwersyteckich. Koszt zagranicznych studiów Stanisława Tarły wyniósł okolo 10 tys. florenów, ale śladów obecności przyszłego arcybiskupa lwowskiego nie ma na żadnej uczelni ${ }^{12}$. Mikołaj Pac uchodził za wykształconego, a nawet uczonego męża, chociaż nie wiemy, gdzie się kształcil. O niektórych z nich zachowaly się opinie współczesnych, świadczące o ich rozleglych horyzontach intelektualnych i dużej erudycji, znajomości języków obcych, zainteresowaniach bibliofilskich, inwestowaniu w szkolnictwo, opłacaniu studiów członkom swoich rodzin oraz fundowaniu stypendiów dla niezamożnych a zdolnych młodych Polaków. Spora grupa biskupów odbyła tzw. edukację dworską. Wojciech Baranowski, Jan Łaski, Wincenty Przerębski terminowali w kancelarii królewskiej. Zaczynali jako sekretarze, a kończyli, piastując najwyższe godności państwowe podkanclerzego i kanclerza wielkiego koronnego - i trudno im zarzucić brak kompetencji. Z dworu królowej Bony wywodzil się biskup chełmski Adam Pilichowski, który był specjalistą w zarządzaniu dobrami królowej, miał też opinię świetnego mierniczego. Jako pisarz w kancelarii Bony oraz w sekretariacie królewskim pracował Walerian Protasewicz, późniejszy biskup łucki, następnie wileński, założyciel kolegium jezuickiego w Wilnie. W realizację pruskiej polityki Zygmunta Starego zaangażował się Wincenty Przerębski. W imieniu Zygmunta Augusta posłował do Inflant późniejszy biskup tych ziem Aleksander Mieliński, który według ówczesnych opinii znał biegle kilka języków, ale o jego edukacji prawie nic nie wiemy. Paweł Tarło był przez pewien czas sędzią ziemskim.

Na dworze biskupa poznańskiego Uriela Górki i w atmosferze tego dworu wyrastał przyszły biskup kujawsko-pomorski Łukasz Górka. Ze szkoły biskupa wileńskiego Jana wywodził się biskup lucki Jerzy Chwalczewski, zarządca dworu litewskiego Zygmunta Augusta, sprawny organizator i wykonawca agrarnych reform królowej Bony. Ośmiu biskupów, których miejsca edukacji szkolnej nie znamy, zdobywato przyszle kwalifikacje zawodowe na dworze królewskim bądż na dworach biskupich. Ówczesne szkoły dworskie przygotowywały młodzież do praktycznej działalności w kancelariach, zapoznawaly z tajnikami dyplomacji, uczyły języków, obowiązującej etykiety i manier, były przepustką do wielkiego świata polityki i kultury. 
Uwzględniając różnorodne, niezinstytucjonalizowane formy ówczesnego przygotowania zawodowego, stwierdzimy więc, że prawie wszyscy XVI-wieczni senatorowie duchowni mieli za sobą jakąś edukację. O szerokich horyzontach intelektualnych ówczesnych biskupów może świadczyć ich różnorodna działalność kulturalna, która wymaga dalszych badań. O arcybiskupie lwowskim Janie Sienieńskim, który awansował $\mathrm{z}$ wojskowego na biskupa, pisano, że nie znał łaciny, a duchowienstwo kpiło z niego - była to jednak nominacja polityczna ${ }^{13}$. Nie zmienia to jednak obrazu całej elity - wykształconej i dobrze przygotowanej do wypełniania nałożonych na nia zadań na rzecz państwa i Kościola.

\section{Przypisy}

${ }^{1}$ M. Kromer, Polska, czyli o położenilu, ludności, obyczajach, urzędach i sprawach publicznych Królestwa Polskiego księgi dwie, Olsztyn 1977, s. 182. Konstytucja określała również kolejność zasiadania w senacie.

${ }^{2}$ A. Wyczański, Między kulturq a politykq. Sekretarze królewscy Zygmunta Starego (1506-1548), Warszawa 1990, s. 137; L. Kolankowski, Kandydatura Jana Albrechra Hohenzollerna na biskupstwo płockie, Lwów 1906.

${ }^{3}$ Kościót w Polsce, red. J. Kłoczowski, t. 2, Kraków 1969, s. 111 i n.

${ }^{4}$ A. Wyczański, op.cit., Aneks; M. Korolko, Seminarium Rzeczypospolitej Królestwa Polskiego. Humaniści w kancelarii królewskiej Zygnunta Augusta, Warszawa 1991, Aneks; L. Kieniewicz, Sekretariat Stefana Batorego. Zbiorowość i kariery sekretarzy królewskich, w: Społeczeństwo Staropolskie, red. A. Izydorczyk, A. Wyczański, t. 4, Warszawa 1986, s. 62-67.

${ }^{5}$ M. Kromer, op. cit., s. 61.

${ }^{6}$ S. Kot, Źródła do historii wychowania, cz. 1, Kraków 1929, s. 236.

${ }^{7}$ H. Barycz, Polacy na studiach w Rzymie w epoce Odrodzenia 1440 - 1600, Kraków 1938, s. 170. Dane o poziomie wykształcenia czerpano z biogramów w Polskim Słowniku Biograficznym. Pełną bibliografię akt uniwersytetów europejskich, na których bywali Polacy, zamieszcza S. Ciara, Senatorowie i dygnitarze koronni w drugiej potowie XVII wieku, Wroclaw 1990, s. 30 - 31.

${ }^{8}$ Kościót w Polsce..., s. 117.

${ }^{9}$ Ibidem.

${ }^{10}$ Ibidem, s. 122.

"Relacje nuncjuszów apostolskich... o Polsce od roku 1548 do 1690, t. 2, Berlin 1864, s. 234 i n.

${ }^{12}$ J. Fijalek, Tarlowie, znakomilego rodu początki iświetnośc, „Przegląd Historyczny” 10, 1910, s. 52.

${ }^{13}$ Bartłomiej Zimorowic określił rządy Sienieńskiego mianem komedii czynionej ze śmiechem i przy oklasku słuchaczy, H. Kowalska, Sienieński Jan, Polski Słownik Biograficzny, t. 37, z. 2, 1996, s. 182. 